\title{
Flora Tristan: jornalismo militante em tempo de revoltas
}

\author{
Maria Inês Amarante \\ Pontifícia Universidade Católica de São Paulo (PUC-SP)
}

\section{Flora Tristan: jornalismo militante em tempo de revoltas}

Resumo: O presente artigo, fruto de uma pesquisa bibliográfica e documental, apresenta o itinerário de Flora Tristan e sua inserção no jornalismo da época, na primeira metade do século 19. Procura-se mostrar diversos aspectos da condição feminina na sociedade francesa em transformação pós-revolucionária e no início da Revolução Industrial, o pensamento de seus teóricos mais relevantes e a vivência da autora diante dessa realidade. O fio condutor do trabalho é a apresentação do perfil bio-bibliográfico de Flora. Através da cronologia comentada de suas obras e textos, publicados após a viagem que empreende à América Latina, evidencia-se a extensão dos ideais utópicosocialistas que defendeu e sua crença em formas mais justas de organização social em prol dos direitos das mulheres e de uma união nacional de trabalhadores. O combate literário e militante da escritora e a coerência de suas ideias de vanguarda lhe garantiram um lugar de destaque na história do pensamento feminista.

Palavras-chave: Flora Tristan, feminismo, imprensa, Revolução Industrial.

\section{Flora Tristan: Militant Journalism in Times of Revolt}

Abstract: This article, which is the fruit of bibliographic and document research, presents the itinerary of Flora Tristan and her insertion in journalism of her time, at the first half of the $19^{\text {th }}$ century. It identifies various factors of the feminine condition in post-revolutionary French society under transformation and at the beginning of the Industrial Revolution, the thinking of its most important theoreticians and Tristan's experience in relation to this reality. The central focus of the study is the presentation of a bibliographic biography of Flora Tristan. A commented chronology of her work and texts, published after a trip that she took to Latin America, reveals the utopiansocialist ideas that she defended and her belief in more just forms of social organization in support of women rights and a national workers union. Her literary and militant activities and the strength of her vanguard ideas, guarantee her an important place in the history of feminist thinking.

Key words: Flora Tristan, feminism, press, Industrial Revolution. 


\section{Introdução}

Ao nos debruçarmos sobre a vida de Flora Tristan, o que mais nos impressiona é o seu vanguardismo. E, para além dele, o desejo de reconhecimento que ela demonstrou em seus 41 breves anos de vida, militância e obra.

De fato, esta menina nascida em Paris no dia 7 de Abril de 1803, e que fora batizada com quatro nomes - Flora, Célestine, Thérèse, Henriette -, e um sobrenome estrangeiro, Tristan Moscoso, era filha ilegítima do casamento não reconhecido de um militar da aristocracia espanhola, oriundo do Peru (PERRUCHOT, 1961, p. 11), e uma mãe burguesa refugiada na Espanha após a Revolução Francesa. Quando da morte do pai, seus sonhos foram desfeitos pelas dificuldades de toda ordem.

Foi talvez sua natureza orgulhosa que a levou a reagir contra um marido possessivo e encontrar a força necessária para lutar sozinha a fim de prover às necessidades de sua família, não sem deixar de ser, enquanto mulher separada, vítima do preconceito. Este fato, seguramente, marcou sua vida, a ponto de despertar-lhe um sentimento de não pertencimento social profundo e intenso.

Entre 1833 e 1834, ela realiza uma viagem histórica ao Peru, em busca da família paterna, que transformou sua vida ${ }^{1}$. Ao partir, pária em fuga; ao voltar, escritora e militante pela condição feminina e os direitos dos trabalhadores franceses.

Pode-se reconhecer em Flora uma verdadeira jornalista, sendo que o ideal que perseguiu foi $a$ mudança social. Se uma das características do jornalismo é o elo intrínseco que tem com a vida cotidiana e a informação transforma a realidade vivida, a leitura da obra de Flora nos leva a perceber o quanto a expressão de suas reflexões sobre o seu tempo visava esta transformação. Daí o significado social que teve para o século 19, que pretendemos abordar neste breve artigo.

Desde seus primeiros textos, ela assume um compromisso com a verdade como um pacto estabelecido com o leitor (TRISTAN, 2000, p. 42):

Todo escritor deve ser verdadeiro: se não se sente com coragem para fazê-lo, deve renunciar ao sacerdócio que assume de instruir seus semelhantes. A utilidade de seus escritos resultará das verdades que eles conterão e, deixando às meditações da filosofia a descoberta das verdades gerais, não pretendo falar aqui senão a verdade no relato das ações humanas.

Ou ainda, ao lembrar (TRISTAN, 2000, p. 43): "Ódios poderão se sublevar contra mim: mas, ser de fé, antes de tudo, nenhuma consideração poderá me impedir de dizer a verdade sobre as pessoas e as coisas." Verdade ou expressão de linguagem para atrair o público, à moda romântica, o fato é que, como mulher de seu tempo, a literatura era uma forma de praticar o jornalismo, pois quase todos os escritores dedicavam-se a crônicas e artigos que eram publicados na imprensa e ali exerciam notável influência.

$\mathrm{Na}$ França, no final do século 18, mesmo que os instrumentos privilegiados de expressão intelectual continuassem sendo o livro ou a brochura, a imprensa representava uma força em progressão, apesar de estar sob censura desde $1792^{2}$. Nas décadas de 1830-1840, o jornalismo popular cresce em público e tiragem e contribui na comercialização de jornais, que passaram a ser o modo de expressão do feminismo (PERROT, 2008, p. 32-34). As mulheres se infiltram nos folhetins e, aos poucos, da imprensa especializada na moda, como o Journal des dames (1750-1778), passam a exprimir o desejo de emancipação em outras publicações.

A escrita do diário, segundo Perrot (2008, p. 2930) "era um exercício recomendado, principalmente pela igreja, que o considerava um instrumento de direção de consciência e de controle pessoal" [...] é graças a eles que se ouve o 'eu', a voz das mulheres."

\section{Uma mulher face à sociedade de seu tempo: a condição feminina}

Flora Tristan refletiu as grandes transformações da sociedade francesa do início do século 19, na qual a mulher não tinha um lugar bem definido.

A primeira grande perturbação ocorrida em sua vida deu-se quando Napoleão desapropriou os bens estrangeiros, decisão que deixou sua mãe viúva no mais completo abandono social. A segunda, deve-se à realidade das leis, que produziu uma situação inesperada e difícil para ela, mulher separada.

Apesar dos ideais feministas circularem na França desde Christine de Pisan, no século 15, foi somente após a Revolução Francesa, a partir da mudança nos direitos políticos dos homens, que as mulheres começam a exigi-los para elas mesmas. Levantaram a bandeira da liberdade contra o poder monárquico ao lado dos homens e começaram a participar de todas as transformações de seu tempo. Reivindicavam para si o papel de cidadãs numa socidade pósrevolucionária e clamavam por mudanças. Para tanto, era imperioso obrigar o governo a tomar decisões legais a seu favor.

Os grandes teóricos antes da Revolução Francesa demonstravam ainda preconceitos contra as mulheres. Rousseau (1712-1778) declarava que eram feitas "para agradar ao homem"; Voltaire (16941778), em seu Dicionário Filosófico, afirma que as mulheres eram geralmente inferiores ao homem pelo corpo e o espírito. Acrescenta ainda que era necessário aperfeiçoar este último. Mais tarde, Napoleão 
declararia ao Conselho de Estado (ARON, 1980, p. 7): "se existe uma coisa definitivamente anti francesa, é que elas possam fazer aquilo que desejarem.". Poderíamos ainda citar muitos homens de letras que, como Proudhon, se opunham de modo obstinado a qualquer manifestação em prol da emancipação feminina, mesmo que esta traduzisse percepções masculinas. Proudhon, sobretudo, em um dado momento, atacaria Fourier, quando este defende o compromisso das mulheres como força ativa na sociedade de produção (DEBÛ-BRIDEL, 1947). O referido autor lembra que Gaschon de Molènes, em sua obra Mulheres poetas, de 1842, declarou impunemente: "As mulheres nasceram para pôr no mundo outra coisa que volumes de versos. Seguramente, entre as mulheres que escrevem... pode haver mulheres de espírito, mas eu sempre preferirei a elas a mulher de espírito que não escreve!"

Em 1790, quando Condorcet reivindica "a Admissão da Mulher ao direito de cidade", parece que o temor dos homens era que, com uma participação política mais acentuada, a mulher abandonasse o seu habitat natural, "o lar", e seu papel histórico, o de "esposa e mãe", uma visão do papel feminino que, por muito tempo, fez parte da mentalidade europeia, apesar das pressões dos revolucionários.

Apenas as mulheres que não faziam parte do senso comum, ou que gozavam de um estatuto privilegiado, puderam escapar desse constrangimento. Foi o caso de Madame de Staël (1766-1817), George Sand (1804-1876) ou de Marie de Agoult (Daniel Stern, 1835-1844), que embora enfrentassem dificuldades, puderam superá-las facilmente, tanto pelo talento e a cultura como pela posição social que ocupavam.

De fato, as leis francesas sobre o casamento, mais flexíveis pouco depois da Revolução, ficaram rígidas no início do século 19. O divórcio havia sido introduzido em 1792, mas o Império limitou-o em 1803 e, sob pressão da Igreja Católica, o governo da Restauração o aboliu em 1816. Apenas no final do século ele seria restabelecido. Assim, a mulher casada era condenada pela lei e pela sociedade - juridica e eticamente - à desapropriação, já que os homens geriam todos os bens da família e podiam desfalcar suas mulheres impunemente. Era necessário ser uma mulher afortunada para poder gerir seus bens pessoais, mesmo diante da constante ameaça de bloqueio de uma carreira ou tarefas que poderiam colocá-las diretamente em rivalidade com os homens. Contudo, a fortuna representava para elas um modo de libertação.

A partir de 1790, Olympe de Gouges (1748-1793), revolucionária cujos escritos eram dedicados às questões sociais e concepções políticas de vanguarda, já havia tocado no ponto essencial em sua Declaração dos direitos da mulher e da cidadã. Fazia menção a um direito à tribuna para todas aquelas que tivessem contribuído para com a Revolução, da mesma maneira que o atribuído aos homens. Porém, no início do século 19, a sociedade francesa ainda estava longe de reconhecer esse direito, como demonstram as medidas repressivas tomadas pelo governo para impedir que as mulheres se unissem a fim de discutir suas opiniões ou manifestar-se legalmente.

Nos tempos do Consulado e do Império, em que a causa feminina era reprimida, haja vista o controle e fechamento de todos os clubes femininos onde as mulheres levantavam suas vozes, em uníssono, para reclamar seus direitos, alguns reformadores vão trazer uma nova esperança. Tal foi o caso dos sansimonistas e fourieristas que contribuíram para a formação dos ideais sociais de Flora Tristan.

As teorias socialistas e utopistas desses pensadores denunciavam um sistema que massacrava as famílias. Entre eles figurava o Conde de Saint-Simon (1760-1825), descrito como um homem de espírito aberto e utópico, frequentemente profético e mestre-pensador de uma escola filosófica, uma sociedade econômica, bem como de uma seita religiosa. Em sua revista $A$ Indústria, inicia um combate em prol da emancipação dos trabalhadores em geral. Prega um "novo cristianismo", defende também qualquer ser explorado pela lei do mais forte.

As mulheres só podiam aplaudir estas ideias novas. Após a morte de Saint-Simon, em 1825, os adeptos sansimonistas se agruparam em torno de Prosper Enfantin (1796-1864), seu discípulo mais conhecido. A metafísica e o feminismo estavam presentes em seus discursos e estudos, razão pela qual Enfantin se auto denominou "pai" e transformou o movimento numa "religião racional". A metafísica era, na nova concepção de Deus, espírito e matéria ao mesmo tempo, inteligência e força, sabedoria e beleza.

$\mathrm{O}$ feminismo estava ligado a este conceito que tanto sensibilizava Flora. Os sansimonistas consideravam a mulher como um ser superior devido à sua capacidade de reproduzir. Assim, ela era vista, ao mesmo tempo, como matéria e espírito: a carne, o amor, "a vida na sua unidade". Devia ser liberada do domínio masculino e, por conseguinte, do casamento - para vincular-se a eles livremente. Defendendo o pensamento de que "o homem e a mulher constituem solidariamente o indivíduo social” (MICHAUD, 1984), proclamavam a igualdade dos sexos. A luta para o restabelecimento do divórcio fazia parte das preocupações essenciais dos sansimonistas.

Entre as mulheres seguidoras da doutrina, operárias e burguesas tinham seu lugar. Muitas delas tornaram-se também militantes, tanto pela causa operária como pelo acesso das mulheres ao poder político, ou então prosseguiram um itinerário mais místico ao lado do "pai". Outras ainda, como Suzanne Voilquin (1801-1878), Désire Véret (1810-1891), Eugénie Niboyet (1799-1883), Jeanne Deroin ou Pauline Roland (1805-1894) ${ }^{3}$, dedicaram-se ao jor- 
nalismo pelas causas feminista, política e social de seu tempo, em jornais como o sansimonista La femme libre (PERROT, 2008, p. 34).

Os utopistas partem também de um pensamento romântico, até mesmo misterioso e místico que, ao falar de amor, atribuiam ao mesmo tempo à mulher um papel redentor: é através dela que os homens serão salvos.

A educação ganha destaque na escola sansimonista, pois é vista como pilar de uma sociedade harmoniosa, ordenada e fortificada. Porém, se eles têm muitos adeptos, preocupam também alguns burgueses que os consideram "subversivos e contestatários".

Charles Fourier (1772-1837) levava a cabo sua ação paralelamente à dos sansimonistas. Em sua Teoria da unidade universal, desenvolvida entre 1822-1838, propõe um plano para a organização do trabalho que pode ser considerado como um esboço do socialismo científico: o sistema falansteriano, no qual produtores e consumidores poderiam viver em comunidade, em lugares ditos falanstérios, espécies de palácios nos quais todos teriam direito ao trabalho, à educação, saúde, ao alimento, vestuário e à vida coletiva. As tarefas seriam de acordo com as inclinações naturais e os trabalhadores receberiam em troca dividendos. Este sistema era baseado na providência divina e tinha como objetivo final a harmonia que poderia ser atingida por meio da ordem, liberdade, opulência, alegria e da paz na vida de todos.

Fourier tinha previsto uma nova moral contra a velha moral cristã baseada na obrigação e no sacrifício. Para ele, todos os seres livres deviam associarse espontaneamente entre si. O desenvolvimento dos homens e das mulheres, sem distinção, viria deste livre jogo das paixões, onde não havia lugar para a moral, nem para a hipocrisia social. A mulher, em seu sistema, era então duplamente livre: da autoridade masculina e da servidão das tarefas domésticas. O discípulo mais conhecido de Fourier foi Victor Considérant, que desempenhará um papel político importante, através do seu jornal A falange.

\section{Os ideais libertários de Flora}

Desde pequena, Flora acostumou-se a ver o pai receber em sua residência parisiense Simon Bolivar. Os ventos novos da Revolução Francesa transformaram este personagem controverso em republicano convicto. Em 1807, na última das cartas que escreve à sra. Tristan mãe (TRISTAN, 1838c), Bolívar manifesta sua decisão de retornar à América, onde acredita poder traçar um novo destino. No ano seguinte, na Venezuela, inicia uma campanha pela independência de seu país, tornando-se Simon, o Libertador.

Se a América Latina, por muito tempo, assombrara o imaginário dos escritores europeus, a maior parte das obras produzidas pouco depois da conquista do novo continente são descrições da natureza e dos habitantes nativos.

Embora não estivessem preparados para compreender as evoluídas civilizações que floresceram em berço latino-americano, as indagações sobre os habitantes deste continente foram, gradualmente, constituindo matéria literária e filosófica importante. Desde o século 16, os escritores franceses foram os primeiros a debater essas questões com um pouco mais de liberdade de espírito, na medida em que se sucediam as expedições para o Novo Mundo.

Durante a travessia de navio até o Peru, Flora Tristan pôde aprofundar alguns de seus conhecimentos dessa literatura. Em Peregrinações de uma pária (2000, p. 138), ela revela suas leituras: Voltaire, Byron, Chateaubriand, as fábulas de La Fontaine, Lamartine, Victor Hugo, Walter Scott e, sobretudo, Bernardin de Saint-Pierre. A escolha desses escritores é bastante significativa: com exceção de La Fontaine, todos viveram no Século das Luzes, ou na época romântica, e a maior parte deles produziu literatura de viagem. Bernardin de Saint-Pierre (1737-1814), particularmente, defende as harmonias da natureza, justifica a Providência contra o ateísmo e opõe as leis naturais às sociais. Como outros escritores e filósofos, ele também combaterá a escravidão. Na única visita que faz à Biblioteca de Lima, Flora observa, com satisfação, uma vasta coleção de obras francesas de Voltaire, Rousseau, Madame de Staël e Madame Roland.

De volta à França, tudo mudara em sua vida. Durante a viagem, ela capta o sofrimento além do seu: na vida rude dos marinheiros, no olhar dos seres dominados pela escravidão e das vítimas da guerra, no coração das mulheres que, na outra extremidade do mundo, se encontravam também submissas a um casamento e às convenções de uma sociedade patriarcal que as oprimia. Testemunha da miséria humana, entra em comunhão com outros sofredores. Sentindo suas penas, tentará buscar as causas e tomará consciência de que as injustiças que lhes são impostas são o resultado da violência da sociedade baseada no lucro.

$\mathrm{Na}$ França republicana, por toda a parte havia um confronto de ideologias, a revolta inscrevia-se numa busca romântica pela igualdade pessoal e coletiva. Os filósofos e os sonhadores utópicos tentavam traduzir a realidade social através de soluções cósmicas que vinculavam a diversidade e a unidade, a transformação e a continuidade.

O empobrecimento da população era uma nova realidade, fruto do crescimento demográfico e o aumento da massa operária. Após o malogro da democracia, em julho de 1830, apreensões sociais de toda espécie começaram a fazer parte das preocupações gerais e os protestos dos trabalhadores eram violentamente repri- 
midos. No entanto, se os idealistas queriam conscientemente uma mudança social, os prejuízos da Revolução Industrial vinham opor-se a esses ideais.

As leis repressivas, votadas entre 1834 e 1835, proibiam a formação de associações e limitavam o poder da imprensa. Conspirações e sociedades secretas se multiplicavam, bem como as controvérsias entre os reformadores. Cada qual propunha, à sua maneira, a solução contra a exploração do ser humano.

A imprensa se enriquecia de informações e debates, difundindo e revelando novos talentos pela publicação de romances folhetinescos. Os sansimonistas e os fourieristas tinham seus próprios jornais. As mulheres faziam-se notar por seus escritos e iniciavam a luta pela emancipação. Esta tomada da palavra concretiza-se pela criação de uma imprensa feminista e por uma participação nos movimentos ideológicos que vão marcar toda uma época. Entre as pioneiras, destaca-se Eugénie Niboyet que cria um jornal de mulheres em Lyon. Divididos entre teorias liberais e sociais, os escritos da nova geração romântica destes anos 1830 multiplicam-se.

É nesta efervescência que Flora Tristan busca contato com todos os que, por seus pensamentos e ações, lhe parecem susceptíveis de trazer uma solução aos problemas sociais. Em 1836, pensa em tornar conhecida a condição feminina no Peru e, antes da publicação de Pérégrinations d'une paria, revela ao público francês alguns trechos de seu relato num artigo publicado pela Revista de Paris, As mulheres de Lima, que posteriormente constituirá capítulo dessa obra autobiográfica. Segue-se a este, $O s$ conventos de Aréquipa: história de Dominga -, publicado pela mesma revista (TRISTAN, 1980a, p. 66). Como o texto está na primeira pessoa, os leitores podem sentir-se mais próximos do que foi testemunhado pela viajante.

Flora prosseguirá a busca por sua cidadania, apresentando duas petições à Câmara dos Deputados. À primeira, Petição para o restabelecimento do divórcio ${ }^{4}$, de 20 de dezembro de 1837, anexa um exemplar de Pérégrinations d'une paria, que na sua opinião ilustra as desgraças das mulheres diante da indissolubilidade do casamento. A segunda, escrita em 10 de dezembro de 1838, após o atentado que sofrera por parte do ex-marido Chazal, é a Petição para a abolição da pena de morte 5 (TRISTAN, 1838b), publicada no Journal du Peuple, em 16 de dezembro de 1838, de onde salienta a inutilidade desta punição numa sociedade onde todas as injustiças contra o povo o induz aos crimes mais diversos. $\mathrm{Na}$ lista destas injustiças, não deixará de citar a discriminação jurídica da mulher, devido à qual ela própria sofrera penosas consequências.

No momento em que o desejo de instruir seu semelhante e tornar-se útil à sociedade se lhe impõe, sente-se impulsionada à ação, o que significava reve- lar, através de seus escritos, suas próprias experiências, traduzir a palavra dos que não tinham voz e difundir suas reflexões. Este compromisso será total e tornarse-á o combate de sua vida. Pensa em alterar, primeiramente, a condição das mulheres. Via a possibilidade de fazê-lo não apenas através da revelação de seus dissabores, mas também - e principalmente - pela união e a instrução, propostas que seguem a corrente dos ideólogos da época. Assim, em 1835, dá corpo a seu projeto através da publicação de um panfleto feminista: Nécéssité de faire bon accueil aux femmes étrangères ${ }^{6}$, que assinará com suas iniciais (Madame F.T.). Este texto constitui mais do que um apelo à fraternidade, pois defende uma união das mulheres em torno de uma organização de acolhida para todas aquelas que, vindas de outros horizontes, encontram-se sozinhas em Paris. Ela propõe uma tribuna para as mulheres marcada pela divisa - Virtude, Prudência e Publicidade. Prevê que todas possam falar no anonimato sobre as injustiças que sofrem e, também, que a organização tome a palavra em nome de todas aquelas que não podem fazê-lo.

No dia 21 de agosto de 1835, Flora escreve a Fourier a fim de oferecer-lhe seus primeiros escritos e propor-lhe ajuda para a missão humanitária que almeja. Os contatos que mantém com Fourier serão constantes e ela continuará muito atenta às publicações do jornal A falange, para o qual escreve uma carta em agosto de 1836 (TRISTAN, 1980a, p. 61), e que representará seu primeiro contato profissional com a imprensa, contestando a organização social defendida por Considérant. Através desta carta, já antecipa os princípios que desenvolverá em sua obra União Operária ${ }^{7}$ (L'Union Ouvrière, TRISTAN, $1843^{8}$ ), segundo os quais uma vulgarização do pensamento fourierista facilitaria sua divulgação no seio da classe operária.

Considera igualmente que naquela sociedade liberal, os ideais sansimonistas representavam "o fim da viuvez cristã", e o grande casamento humanitário pela libertação moral da mulher.

Contudo, se a nova ordem moral de liberdade no amor vai atraí-la, ela seguramente não estava preparada para este liberalismo, como afirma Baelen (1972, p. 122). Suas divergências com a escola dirigida pelo sansimonista Enfantin eram causadas pelo princípio de hierarquia imposta por este e que lhe conferia um monopólio nas decisões e autoridade própria para excluir as mulheres.

Mesmo que Flora não revele suas tendências políticas, a publicação das Cartas de Bolívar ${ }^{9}$ (Lettres de Bolivar - TRISTAN, 1838a) no jornal Le Voleur, em 31/07/1838, é bastante significativa. Não apenas essas cartas ressaltam a importância das lutas que este personagem histórico efetuou contra a opressão dos povos, mas também lembram os ideais republicanos. Além disso, os textos de Bolívar que seleciona constituem 
um ataque frontal aos bonapartistas, cuja influência ainda simbolizava a opressão social das mulheres.

Até mesmo em sua única obra romanceada, Méphis ou le prolétaire ${ }^{10}$, publicada em 1838, a escritora aproveitará para fazer de seus personagens porta-vozes de suas aspirações sociais. Peregrina incansável, volta à Inglaterra em 1836 e $1839^{11}$. Durante o ano que segue esta última viagem, publica Promenades dans Londres ${ }^{12}$, em 1840 (TRISTAN, 1978). Seus passeios londrinos marcam uma mudança decisiva nas ações que inicia. Os quadros da sociedade inglesa que pinta com uma cruel objetividade precedem as páginas de Engels, La situation de la classe ouvrière en Angleterre ${ }^{13}$, que se tornarão célebres $^{14}$. Após haver testemunhado a vida dos escravos peruanos, descobre na classe operária londrina outro universo de explorados, acrescentando a prostituição às misérias relatadas.

Em 1837, conhece Robert Owen (1771-1858), pioneiro do socialismo inglês, que procurava remediar os males da sociedade industrial pela organização da classe operária, e dedica a ele um capítulo de sua obra Promenades dans Londres, na edição de $1842^{15}$. Contudo, não se filia a nenhuma destas escolas, declarando não ser "nem sansimonista, nem fourierista, nem oweniana", talvez o seu modo de protestar contra as rivalidades existentes entre os ideólogos socialistas, num momento histórico que impunha, antes de tudo, a união e a convergência de ideias.

O interesse pela terrível situação do mundo operário não implicará no recrudescimento da luta pelas mulheres que sofrem uma dupla exploração: pelo sexo e a condição social. O momento era chegado, segundo ela, de lutar por todo o proletariado, no qual as mulheres representavam "o proletário do proletário".

Flora tornar-se-á amiga de Marceline DesbordesValmore (1786-1859) e, nos anos 1840, da militante socialista Pauline Roland (1805-1852). Em 1836, durante as reuniões semanais que o jornal Gazeta das mulheres organizava, encontra igualmente a jornalista Eugénie Niboyet. Em uma das cartas que lhe dirige, revela projetos de colaboração conjunta numa publicação feminista.

Após esta obra, expandirá suas relações com os escritores do mundo do trabalho a fim de divulgar à classe operária francesa informações sobre a situação dos trabalhadores ingleses, levando-a a refletir sobre sua própria condição. Manterá uma extensa correspondência com estes filósofos operários que tentavam restabelecer o "compagnonage", associação operária de solidariedade, próxima da maçonaria.

Conhece Agricol Perdiguier (1805-1875), trabalhador-escritor que foi fonte de inspiração para Eugène Sue (1804-1857), Victor Hugo (1802-1885) e George Sand, uma das primeiras a falar de tal associação. Intensificará contatos com outros trabalhadores ligados à causa operária, como Jules Vinçart (1796-1882).
Aproxima-se de editores e diretores de publicações diversas e escreve relatórios que distribui à personalidades do mundo das letras e da imprensa, como Louis Blanc (1811-1882), por ocasião da publicação da União Operária, em 1843. Publica no jornal dos trabalhadores La Ruche e prossegue sua ação graças aos inúmeros assinantes. Proporá um artigo à Revista Independente, dirigida por Sand, mas o texto nunca será publicado (TRISTAN, 2000, p. 40).

Armada de sua bagagem de vivências e viagens, Flora investe-se na defesa dos trabalhadores enfrentando a ordem burguesa. Além da união dos trabalhadores franceses, também propunha uma coesão estreita da classe operária mundial. De maneira concisa, resume suas reivindicações sobre o papel que deviam assumir as massas operárias: "a classe operária tem o direito de existir como tal e os outros devem respeitá-la. [...] a emancipação dos trabalhadores será a obra dos próprios trabalhadores"16. Afirmará igualmente que o internacionalismo faria desaparecer o mito do nacionalismo e, com ele, as guer$\operatorname{ras}^{17}$ (TRISTAN, 1844, p. 99):

\begin{abstract}
Na França todos são franceses, inclusive nas províncias. Está próximo o dia tão desejado em que seremos todos homens, irmãos, sem nos diferenciarmos pelos nomes de ingleses, alemães, franceses etc [...] O essencial é fazer com que as crianças compreendam que o nosso globo é um grande corpo humanitário... e que odiando ou fazendo o mal a seus irmãos em humanidade, é a eles mesmos que odeiam e a quem fazem o mal. É necessário fixar nos espíritos esta dupla noção, esta individualidade do grande corpo humanitário e esta solidariedade entre as nações e os indivíduos.
\end{abstract}

Para dar forma à sua concepção da unidade da classe operária, busca uma união mais sólida. Ela compreende que deve dirigir-se pessoalmente aos círculos operários de toda a nação, atar laços imediatos com trabalhadores de todas as regiões francesas. Imbuída do espírito de "mulher-messias", deixa Paris em direção à Auxerre no dia 12 de abril de 1844. Será a primeira etapa de seu "Tour de France". Em seguida, prossegue a viagem para Dijon, Chalon, Saint-Etienne, Lyon, Marselha, Avignon, Toulon, Montpellier, Béziers, Carcassonne, Toulouse e Bordéus. Em cada parada, organiza reuniões, faz visitas a personalidades importantes, oficinas de trabalhadores, tenta um trabalho verbal de sensibilização até o esgotamento físico, que culmina com sua morte, no mesmo ano.

Em sua obra póstuma, Testamento da pária ${ }^{18}$, publicada por Constant, Flora faz uma homenagem ao jornalista e político Etienne Cabet (1788-1856), exilado em Londres após o fechamento de seu jornal Popular $^{19}$. Embora os pensamentos de Flora e de 
Cabet tenham pontos comuns sob vários aspectos, ele critica de modo polêmico o projeto contido na União Operária. Ela tomará a defensiva dirigindolhe uma carta, no dia 16 de junho de 1843 (TRISTAN, 1980a, p. 177), na qual protesta contra a maneira pela qual ele "desnatura" suas ideias.

A aproximação com o socialista Alphonse Constant, mais conhecido como Abbé Constant, rende-lhe um retrato feito pelo artista, publicado em 1839 na revista mensal As Bonitas Mulheres de Paris. Em 1844, ele publica uma epopeia religiosa e humanista, cujo título é A Mãe de Deus. Numa carta que Flora lhe dirige, em 3 de março de 1844 (TRISTAN, 1980a, p. 193), refere-se a estes escritos como Nossa Mãe de Deus, comungando com ele aspirações sobre a libertação da mulher e dos pobres.

\section{Conclusões}

A primeira e clara constatação que se nos impõe quando nos debruçamos sobre a vida de Flora Tristan é que ela se divide em duas etapas bem distintas quanto à posição que assume diante da realidade: antes e depois de sua viagem à América Latina.

Pode-se dizer que antes era o tempo das provas sofridas, dos sonhos de escape e de revolta desesperada, elementos que, combinados com seu orgulho e caráter altivo, iriam conduzi-la, inevitavelmente, em direção à única saída possível: deixar a sociedade. As portas estavam fechadas às mulheres, sobretudo àquelas de sua condição: sozinha, sem recursos, separada do marido, sujeita a todo tipo de preconceitos, ela vivia à deriva. Seu único alívio era o refúgio nos sonhos de infância e ela se transporta para o país do pai que cedo lhe faltara. Olhar em direção ao passado significava buscar uma proteção junto de tudo o que lhe parecia remoto e ausente, redescobrir um ponto de referência e, talvez, a possibilidade de um futuro promissor.

A viagem representará um distanciamento do que havia vivido, uma nova abertura para o mundo, uma mudança em seu modo de ver. Será para ela um novo tempo de descobertas, o aperfeiçoamento de si mesma, de tomada de consciência e relativização de suas experiências anteriores. Ela mergulha em um universo intelectual que até então havia ignorado. Nos momentos de isolamento das grandes sociedades orga- nizadas, redescobre sua força interior, uma fé inabalável em Deus e um desejo de amar e de crer.

O que Flora Tristan vê no país de seu pai, para além das aparências, serve para ela como prova que a sociedade idealizada não passava de um sonho. A exclusão dos seres que pertenciam, como dirá mais tarde, "ao mesmo corpo humanitário" tinha causas mais profundas que o simples limite imposto pelas fronteiras.

É com serenidade que abandona o Peru para um novo combate na arena da vida, em sua França natal, republicana, desafio que enfrenta solitária e corajosamente. $\mathrm{O}$ depois será o tempo de poder realizar suas ambições, por tanto tempo contidas, e que as experiências de viagem a tinham permitido definir: abraçar uma causa através da escrita.

O percurso literário-jornalístico de Flora Tristan e o engajamento total de sua pessoa em prol das mulheres e dos trabalhadores constituem, sem dúvida, uma sequência lógica e coerente dos ideais de luta pela justiça social que desenvolveu durante suas peregrinações. Nisso, a missão que havia imposto a si mesma, de ser útil a todos os seus semelhantes, parece realizada. Encontra na sociedade francesa de seu tempo o ambiente propício para as mudanças que propõe e as ações que inicia como um sacerdócio. O meio que frequenta é igualmente fértil em ideias, o que pôde contribuir para com seu desabrochar - e reconhecimento - como escritora e militante.

A escrita foi para ela a arma a favor de todos os que sofriam as misérias que ela havia conhecido e da qual escapara - e não é surpreendente que a defesa da causa feminina tenha sido seu primeiro campo de predileção para, posteriormente, ampliar o espectro de suas ações aos operários.

Pode-se dizer que, no grande movimento socialista romântico da época, a participação da escritora lhe confere uma importância singular, como lembrou André Breton, em 1954 (apud BLOCH-DANO, 2001, p. 14): “Talvez não exista um destino feminino como o de Flora Tristan que, no firmamento do espírito, tenha deixado um sulco tão longo e luminoso" 20 .

Deve-se reconhecer que ela preparou o caminho onde muitas mulheres excepcionais e escritoras engajadas, cujas obras sobre a condição feminina marcaram época, puderam passar, como Louise Michel (1830-1905), Clara Zetkin (1857- 
1933), Rosa de Luxemburgo (1871-1919) ou Simone de Beauvoir (1908-1986).

\section{Referências}

ARON, J.-P. Misérable et glorieuse la femme au XIXe siècle. Coletânea de textos apresentada por Jean-Paul Aron. Paris: Edition Complèxe, 1980.

BAELEN, J. La vie de Flora Tristan: socialisme et féminisme au XIXè siècle. Paris: Seuil, 1972.

BERTAUT, J. Une Amazone des Lettres : Flora Tristan. Les Nouvelles Littéraires, n. 55, p. 1-2, Paris, 3 nov.1923.

BLOCH-DANO, E. Flora Tristan. La femme-messie. Paris: Bernard Grasset, 2001.

CASSOU, J. Un fabuleux destin. In: MICHAUD, S. Un fabuleux destin. Flora Tristan. Dijon: L'Harmattan, 1985, p. 1-5.

CUCHE, D. Le Pérou de Flora Tristan: du rêve à la réalité. In: MICHAUD, S. Un fabuleux destin. Flora Tristan. Dijon: L'Harmattan, 1985, p. 19-37.

CZYBA, L. De la révolte à l'A postolat du Tour de France. In: BELLET, R. (Ed.). La femme au XIXe siècle. Littérature et idéologie. Lyon: Presses Universitaires de Lyon, 1978, p. 29-54.

DEBÛ-BRIDEL, J. Fourier: 1772-1837. Paris: Traits, 1947. (Coleção Les classiques de la liberté).

DESANTI, D. Flora Tristan. Oeuvres et vie mêlées. Paris: Union Générale d'éditions, 1973. (Collection 1018, n. 584).

LEPROHON, P. Flora Tristan. Paris: Edition Corymbe/ André Bonne, 1979.

MICHAUD, S. Flora Tristan (1803-1844). Aux Sources du Socialisme. Paris: Ed. ouvrières, 1984.

PERROT, M. Minha história das mulheres. São Paulo: Contexto, 2008.

PERRUCHOT, H. La vie de Gauguin. Paris: Hachette, 1961.

PUECH, J-L. La vie et l'oeuvre de Flora Tristan (18031844) 514 p. Tese. Paris: Librairie des Sciences Sociales et Politiques Marcel Rivière, 1925.

Obras de Flora Tristan

TRISTAN, F. Nécessité de faire un bon accueil aux femmes étrangères, par Madame F.T. Paris: chez Delaunay, 1835. (Bibliothèque Nationale, Paris. Microfiche m.16830).
Lettres de Bolivar. Comentadas. Le Voleur, Paris, 31 jul. 1838a, p. 90-94.

Pétition pour l'abolition de la peine de mort. Endereçada à Câmara dos Deputados no dia 10 de dezembro de 1838. Journal du Peuple, Paris, 16 dez. 1838b, p. 2.

Pérégrinations d'une paria (1833-1834). Paris: Arthur Bertrand, Libraire-Editeur, 1838c, 2 v. in-8., 400/462 p. (Bibliothèque Nationale, Paris. 1-2 microfiche m.7327).

Promenades dans Londres ou l'aristocratie et les prolétaires anglais. François Bédarida (éd.), Paris: La Découverte/Maspero, 1978. (1ère éd.: 1840).

Lettres. Réunies, présentées et annotées par Stéphane Michaud. Paris: Seuil, 1980a.

Le Tour de France. Journal 1843-1844. Paris: Maspero, 1980b.

L' Union Ouvrière. In: ARMOGATHE, D.; J. GRANDJONC, J. (Éd.), Paris: Ed. Des Femmes, 1986 (1ère. éd. 1843).

Peregrinações de uma pária. Tradução de Maria Nilda Pessoa e Paula Berinson. Florianópolis: Ed. Mulheres; Sta. Cruz do Sul: Edunisc, 2000.

\section{Notas}

1 Há controvérsias quanto aos verdadeiros motivos da viagem de Flora ao Peru. Ao partir da França, ela parece disposta a escapar de seu destino para encontrar, em terras mais felizes, outros laços. Segundo diversos autores, o motor da escritora era a herança paterna. Porém, cada um tem um modo bem específicode interpretar suas motivações pessoais. Cuche(1985), por exemplo, considera o deslocamento dela sob o ponto de vista psicológico: a busca de Flora Tristan teria sido motivada pela procura do pai, pela descoberta de uma pátria e, por consequência, pelalegitimaçãode seu status. Para Czyba(1978), o objetivo da viajante era obter a valorização social que a sociedade francesalhe negava. Oescritor Cassou (1985), como Cuche, defende o ponto de vista de uma procura das origens sem, contudo, abordar questões psicológicas. Nota-se que estes argumentos estão bem próximos daqueles evocados pela própria Flora em sua obra autobiográfica. Outros autores preferem, no entanto, privilegiar atese das necessidades materiais daescritora, como Bertaut (1923) ao mencionar "a sucessão que tinha para recolher no Peru” e Desanti (1973) que antecipa a militância ainda por vir ao referir-se à busca pelo dinheiro necessário para o início de uma pretendida ação social.

2 Napoleão Bonaparte calou os opositores e empenhou-se em utilizar o poder dos jornais a serviço de sua propaganda naFrança e no exterior. 
3 Nos anos 1840, ela será perseguida e deportada.

4 Tradução livre da autora.

5 Id.

6 Da necessidade de dar boa acolhida às mulheres estrangeiras, em tradução livre da autora.

7 Tradução livre da autora.

8 Ano da primeira edição.

9 Tradução livre da autora.

10 Méphis ou o proletário, em tradução livre da autora.

11 Há inúmeras controvérsias sobre uma primeira viagem que Flora Tristan teria feito à Inglaterra, em 1831, provavelmente como preceptora, antes de sua partida ao Peru. Porém, este dadoéconfirmado por um de seus biógrafos mais importantes, Puech(1925)

12 Passeios em Londres, em tradução livre da autora.

13 A situação da classe operária na Inglaterra, em tradução livre da autora.

14 Segundo Bloch-Dano (2001, p. 13), Marx e Engels nunca mencionaram Flora Tristan. No entanto, sem dúvida ela foi a precursora da ideia de uma união nacional e mundial de trabalhadores e lutou, durante seu "Tour de France", para reunir os operários em prol dessa causa.

15 "Os remédios: o socialismo de Owen".

16 Publicadoem 1844, na 3.ed. del'Union Ouvrière(TRISTAN, 1986).

17 Id.

18 OTestamento da pária foi publicado em 1846. A esse respeito, o escritor Leprohon (1979) menciona uma lenda que confere a Alphonse Constant (1810-1875) a qualidade de autor da totalidade das obras de Flora, o que seria, segundo ele, uma maneira de justificar o esquecimento dos escritos da autora durante quase todo um século.

19 Em 1840, desde seu regresso à França, Cabet publicaa Viagem em Icarie, onde apresenta o plano de uma sociedade comunista utópica.

20 Tradução livre do texto original em francês.
Maria Inês Amarante

inesamarante@ig.com.br

Doutoranda em Comunicação e Semiótica na Pontifícia Universidade Católica de São Paulo (PUCSP)

Orientadora: Profa. Dra. Jerusa de Carvalho Pires Ferreira

PUC-SP - Programa de Estudos Pós-Graduados em Comunicação e Semiótica

Rua Ministro Godoy, 969, 4. Andar - sala 4A - 08

Perdizes

São Paulo - São Paulo 